\title{
ВИДІННЯ РАДОСТІ У «ФАУСТ-СИМФОНІї» Ф. ЛІСТА ЯК ВТІЛЕННЯ ЕПОХАЛЬНОГО СИМВОЛУ РОМАНТИЗМУ
}

\begin{abstract}
Мета дослідження - виявлення «видіння Радості» у романтичному ідеалотворенні як історичній трансформації концепції мистецтва І. Канта - Л. Бетховена від проторомантизму штюрмерів до романтичної Мрії, поданої у ряді композицій різних авторів і спеціально у «Фауст-симфонії» Ф.Ліста. Методологічною основою роботи $€$ герменевтичний метод аналізу артефактів і мислення у цілому, представлений у працях О. Лосєва, Б. Асаф'єва, Б. Яворського та інших авторів, у тому числі у культурологізованому музикознавстві книг О. Маркової, О. Муравської та їх вихованців. Наукова новизна зумовлена самостійністю підходу до розуміння смислу проекцій генія Л. Бетховена у творчі звершення романтичної доби, оригінальністю герменевтичного аналізу риторичних вимірів виразності творів Ф.Ліста та інших авторів. Висновки. Вперше у культурологічних і мистецтвознавчих дослідженнях виділене кантіанство Л. Бетховена як змістовна ідея Преображення світу мистецтвотворенням в його романтичній символізації, в якій очевидним є зменшення соціального обґрунтування ідеального початку і наростання риторичної умовності втілення, спрямованого до мрії-Марення символістів - на матеріалі бетховеніанства М. Глинки, Р. Вагнера, Г. Малера і спеціально виразності «Фауст-симфонії» Ф. Ліста. Остання подає Видіння жіночого початку світу як Радість-Втіху у вирії маскулінного дисгармонічного буття.
\end{abstract}

Ключові слова: символ, епохальний символ, романтизм, символізм, риторична тема в музиці.

Татарникова Анжелика Анатольевна, кандидат педагогических наук, докторант, преподаватель кафредры хорового дирижирования Одесской национальной музыкальной академии им. А. В. Неждановой

Видение радости в «Фауст-симфонии» Ф. Листа как запечатление эпохального символа романтизма

Цель исследования - выявление «видения Радости» в романтическом идеалотворении как исторической трансформации концепции искусства И. Канта - Л. Бетховена от проторомантизма штюрмеров к романтической Мечте, представленной в ряде сочинений разных авторов и специально в «Фауст-Симфонии» Ф. Листа. Методологической основой работы является герменевтичний метод анализа артефактов и мышления в целом, как это представлено в работах О. Лосева, Б. Асафьева, Б. Яворского и других исследователей, в том числе в культурологизированном музыкознании книг Е. Марковой, О. Муравской и их воспитанников. Научная новизна обусловлена самостоятельностью подхода к пониманию смысла проекций гения Л. Бетховена в творческие свершения романтической эпохи, оригинальностью герменевтического анализа риторических измерений выразительности произведений Ф. Листа и др. авторов. Выводы. Впервые в культурологических и искусствоведческих исследованиях выделено кантианство Л. Бетховена как содержательная идея Преображения мира искусствотворением в его романтической символизации, в которой очевидным является убывание социальной обоснованности идеального начала и нарастание риторической условности воплощения, направленного к мечтеГрезе символистов - на материале бетховенианства М. Глинки, Р. Вагнера, Г. Малера и специально - выразительности «Фауст-Симфонии» Ф. Листа. Последняя подает Видение женского начала мира как РадостьУтешение в вихре маскулинного дисгармонического бытия.

Ключевые слова: символ, эпохальный символ, романтизм, символизм, риторическая тема в музыке.

Tatarnikova Anzhelika, Candidate of Pedagogical Sciences, doctoral candidate, teacher of the Choral Conducting Department of the Odessa National Music Academy A. V. Nezhdanova

Vision to joys in «Faust-symphonies» of F. Lizst as incarnation of epochal symbol of the Romanticism

The purpose of the article is a discovery «visions to Joys» in romantic creation of ideals as history transformation to concepts art to I. Kant - L. Beethoven from protoromanticism Stürmers to romantic to Daydream, presented in a row of the compositions of the different authors and in «Faust-Symphonies» F. Liszt especially. The methodology of the work is the hermeneutic method of the analysis artifact and thinkings as a whole, as this is presented in the work of A. Losev, B. Asafiev, B. Yavorskij and the other researchers, including in culturology musicology to books of E. Markova, O. Muravskaja and their alumnus. The scientific novelty is conditioned by the independence of the approach to understanding the sense projection of genius of L. Beethoven in creative fulfillment romantic epochs, hermeneutic originality analysis of the rhetorical measurements expressiveness of works F.Liszt and others authors. Conclusions. For the first time in culturology and sciences about arts is chosen idea of I. Kant by L. Beethoven as profound idea of the Transfiguration of the world by means creation of art in his romantic symbolization, in which obvious is a decrease social grounding of ideal beginning and growth to rhetorical conventionality of the entailment, directed to daydream-Dream of symbolists - on material of honoring of L. Beethoven to M. Glinka, R.Vagner, G. Mahler and specially expressiveness of «Faust-Symphonies» of F. Liszt. The last gives the Vision feminine begin world as JoyConsolation in the curl of masculine disharmonious being.

Key words: symbol, epochal symbol, romanticism, symbolism, rhetorical theme in music.

() Татарнікова А. А., 2019 
Актуальність теми дослідження визначена множинністю змістовно-стилістичних вподобань пост-авангарду і сьогоденної його трансформації у вигляді «пост-поставангарду», серед яких чинне місце займає символіка культури класичних напрямів Нового часу, в тому числі спадковість від класицистських і романтичних надбань. Затребуваність ідей, закладених генієм Л. Бетховена, виражається у реакції мас-культурних запозичень із бетховенської виразної палітри. Серед них виділяються рокобробки теми Радості з Дев'ятої симфонії, тоді як «Сталкер» А.Тарковського (1980) засвідчив затребуваність саме в даному образі для фіналу фільму, де у «шарпаному», як би на поганій апаратурі подаваному ритмі проходить тема Радості, символізуючи удавану надію душевно скаліченим персонажам того абсурд-кіно. Звучання образу-символу Дев'ятої симфонії Бетховена закладене різнобічною її проекцією у музично-публічні акції минулих століть, коли посилання на певні елементи виразності позначеного твору давало алюзивні додатки до програмних версій тих чи інших артефактів або ідейних зібрань.

Аналіз досліджень і публікацій. Загальні вказівки на вплив тих чи інших аспектів виразності Дев'ятої симфонії на різних авторів вказуються у монографіях, присвячених мистецько-історичним подіям XIX ст., у тому числі в книгах А. Альшванга, Б. Асаф'єва, С. Лобачевської [1; 3; 13], у виданнях 3 історії музики і музичної естетики [11; 9], історії кіно [7]. Але ідейно-культурний вплив образу Л. Бетховена, попри дії специфічно музично-тематичних показників виразності, музикознавчі дослідження минали.

Мета даної роботи - виявлення «видіння Радості» у романтичному ідеалотворенні як історичній трансорормації концепції мистецтва І. Канта - Л. Бетховена від проторомантизму штюрмерів до романтичної Мрії, поданої у ряді композицій різних авторів і спеціально у «Фауст-симфонії» Ф. Ліста.

Виклад основного тексту. Найвидатніші звершення романтиків і реалістів XIX ст. нерідко живилися посиланнями на Дев'яту симфонію Л. Бетховена, маючи на увазі загальний план-ідею твору в розрізненні бетховенського шляху до ідеї оди «До Радості» Ф. Шиллера, втіленої в тексті фіналу, і саме ця ідея виявляється музично піднесеною вписанням Кантати в оркестрально-симфонічне дійство. В роботі М. Маркуса [9] підкреслено обґрунтування бетховенського усвідомлення тексту Ф. Шиллера через естетику І. Канта, що багатогранно представляє кантіанство композитора. І особлива увага надається позиціям естетики Канта щодо місця мистецтва як «моста над прірвою», якою роз'єднані в раціоналізмі філософа Віра і Розум.

І якщо романтики абсолютизували даний підхід, то у Ф. Шиллера і Л. Бетховена вичленований принцип мистецького єднання вказаних протилежностей - через мистецьку ж здатність обминати державно-релігійні фрактори людського буття служінням Красі мистецтва. Такий ракурс бачення має очевидну опору в уявленнях, піднятих «німецькою культурною ідеєю», згідно якої з кінця XVII ст. німецькі землі, розрізані за різними державними кордонами і населені сповідаючими конфесійно-різні католицтво і протестантизм, через культурно-мистецький авторитет Віденської школи заявляли про велич німецького мистецького надбання, долаючи розгубленість і приниженість нації в соціальноекономічному виявленні.

Бетховенський принцип «збирання» теми Радості, що набуває самозначущої виразності у фріналі симфонічного циклу і поступово складається із «зародків» її у прохідній темі (зв'язуюча у сонатних відносинах) у I частині, із теми тріо Скерцо і Варіацій II і III частин, - все це неодноразово було представлено в описах цього твору (див. характеристики Симфонії віденського Майстра у А. Альшванга, Р. Грубера, В. Конен $[1 ; 11 ; 8])$. Відзначимо, що зіставленням саме оркестрового «триптиху» I-ІІІ частин і вокально-хорової IV ч. композитор задає метаструктуру двохфазового вираження, що вказує на ґенезу жанру симфонії як такої.

Адже, як відомо, першосоната називалася симфонією, якщо в інструментальній її оснащеності хоч кілька тактів чи сторінок представляли вокальну музику, тим самим втілюючи, незалежно від часу звучання, єдність земного і Небесного [12, 193-194]. Сказане наводить на висновки про «бетховенське необароко», яке широко простежується у барочних запозиченнях його останніх Квартетів і Сонат. A що стосується двофазовості-двочастинності, подібної до монументальної двохфазовості Дев'ятої симфонії, то маємо це демонстративно у Тридцять другій ор.111 завершальній coнаті c-moll, драматизм та інструментальна сутність першої частини якої урівноважується розгорнутими варіаціями на тему Арієтти у другій частині. Причому, хоральний виклад теми Арієтти, асоційований із протестантською церковністю, «пом'якшений» регістровим розкидом, що наводить на характер співу духовного, але явно позацерковного.

Дещо подібне спостерігається і в Дев'ятій симфонії на рівні «метафазовості»: драматичний інструменталізм у I-III частинах і Кантата у фріналі. В роботі Б. Асаф'єва підкреслюється кантовий, тобто духовний позацерковний сенс теми Радості [3, 287], розгортання якої у фріналі йде за законами високої статики духовного вираження, а не за принципами динаміки-розвитку тілесно-живого, як це показано у першій інструментальній фазі Симфонії. Таким чином, ідея сходження до духовних Висот демонструється у співвіднесеності інструментальної і вокальної фраз Симфонії Л. Бетховена, що стало витоком змістовних символізацій у мистецтві XIX - XX ст.

Виділяємо тільки епохально значущі віхи посилань на Дев'яту Л. Бетховена, з яких найсуттєвішими, можливо, постають події 1842 р. Це був рік початку реформи Р. Вагнера, коли був написаний 
«Летючий Голландець» - опера з біблійними алюзіями до образу Агасфрера, і створення останньої, підсумкової опери М. Глинки «Руслан і Людмила», літургійність якої спеціально досліджував Б. Асафр'єв [4]. Показовим $є$ спокутувальний акт, закладений, незалежно один від одного, і P. Вагнером, і М. Глинкою, у процес написання творів: обидва вибудовували лібрето серйозниходухотворенних і масштабних, кожна у своєму роді, опер, долаючи сміховий текст. У Р. Вагнера це саркастичний переказ містичної легенди, зроблений Г. Гейне у осміювання національних фантазій. А у М. Глинки, як відомо, твір виник на основі перероблення юнацької поеми О. Пушкіна, молода іронічність віршів якої принципово витравлялася із слів, принесених у лібрето.

Обидва твори орієнтовані на тональність Дев'ятої симфонії, але розгортають різні фрази останньої: «Летючий Голландець» демонструє опору на d-moll, лейттема твору (Поклик Голландця) складає інверсію початкової теми бетховенської Симфонії. А «Руслан» М. Глинки орієнтований на кантатністьораторіальність фріналу композиції Л. Бетховена, на її основну тональність D-dur. Для Вагнера істотним був Шлях до Височині, показаної Л. Бетховеном, для М. Глинки - «шаріння у Височині» богатирських видінь національного епосу, літургічний зміст якого, як це відзначено вище, підкреслював Б. Асаф'єB.

Спокутувальна акція творців епохальних композицій у національних школах Німеччини і Росії, судячи з історичних даних, мала позитивний вихід. Адже «Голландець» Р. Вагнера став початком Нової німецької школи, тоді як «Руслан» М. Глинки заклав базис Нової російської школи, - на тлі єдиного джерела, антитетично прочитаного представниками музичного світу.

У симфонічній творчості сучасників і безпосередніх нащадків Л. Бетховена зіставлення із його Дев'ятою уникається, хоча очевидними є наступні аналогії - епічність, співвідносна з Кантатою фріналу твору Л. Бетховена у Дев'ятій (останній!) симфонії Ф. Шуберта (1827), свідомий збіг з тональністю dmoll у Дев'ятій (теж останній!) симфонії А. Брукнера (1891-1894). Але, відзначимо, що вказані автори не наважуються на відтворення бетховенської двоїчної метафазовості у відтворенні першосонати.

Певним підсумком вагнерівського бахіанства у кінці XIX ст. і в проекції наступаючого нового століття стала творчість Г. Малера і, особливо, його Друга симфонія (1894-1903), написана як би за планом Дев'ятої Л. Бетховена. Даний ракурс аналізу має місце в різних дослідженнях, в тому числі і в монументальній книзі І. Барсової [5]. Заміщення Кантати вокальним соло в Симфонії Г. Малера є симптоматичним: Небесне зберігають обранці-парії нації - діти, чистота їх висловлювань в тексті вокального соло - відсторонена від суєтного і складає виняток. Показово, що Г. Малер, наслідуючи план Дев'ятої Бетховена, написав ії у тональності с/C, як би роблячи поступку надзвичайно шанованому ним Й. Брамсу, що вважав ідеалом бетховенського симфонізму П'яту і Шосту симфонії, з яких перша втілена в тональності c-moll із фріналом в C-dur.

Не забуваємо, що Перша симфонія Г. Малера написана в D/d, яку прийнято трактувати як «вступну» до циклу його Симфоній у цілому, тим самим співвідносячи сфери c/C i D/d. 3 Дев'ятою симфонією Л. Бетховена порівнюють Восьму симфонію і симфонію-кантату «Пісня про землю» Г. Малера - але то концепція П. Беккера і його спадкоємців-музикознавців, які так трактують творчий шлях композитора. Щодо самого автора, то його спроба «закрити» пафос порівняння з Дев'ятою Л. Бетховена, знімаючи належну нумерацію з Симфонії-кантати «Пісня про землю» (що відкривається «Застільною піснею про бідування землі», а закінчується «Прощанням» - і вся написана на вірші китайських поетів епохи Тан), засвідчує сама себе як відмову від Краси Єднання.

$\epsilon$ ще один твір, написаний аж у XX сторіччі за Дев'ятою Бетховена. Це Кантата II «Світло очей» А. Веберна на вірші X. Йоне (1935). Позначення цифрою II пояснювалося самим композитором ціннісним посиланням на фінал Дев'ятої Бетховена як на Кантату I, внаслідок чого вебернівська Кантата може бути тільки Другою. У роботі Д. Андросової підкреслюється вказане звернення А. Веберна до бетховенського витоку: «Завершення Кантати в ясному D-dur, наявність на початку фрінальної VI частини проведень теми-серії in $d$ i in $b$ (порівн. із зіставленнями D-dur i B-dur у фріналі Дев'ятої Л. Бетховена), незвична для Веберна розгорненість звучання (півгодинний часовий обсяг) виявляють характерний «синдром Дев'ятої симфонії» в загальноконцепційному значенні» $[2,107]$.

Для А. Веберна діалектика Шляху Л. Бетховена як реалій «долання життєвих випробувань» була неприйнятною. А от «шаріння у височинях» на рівні «розрідженої матерії» уявлень і спостережень у високих горах, відірваних від буттєвих «згущень», - то і є парафразою на фрінал Дев'ятої, зробленою в обсязі «дематеріалізованої важкості» за твором Л. Бетховена. Вебернівський пуантилізм втілює гармонізоване тишою пауз «роїння одиничностей», що є виразником дечого потойбічного по відношенню до тілесної відчутності кантового єднання знаменитого гімну Л. Бетховена.

На тлі наведених пролонгацій «синдрому Дев'ятої» у музиці XIX - XX століть вибудована Ф. Лістом «Фауст-симфонія» вражає фрактурно-конструктивним уподібненням Дев'ятій, тоді як програмні назви і Симфонії у цілому, і заголовки окремих частин пов'язані із дивними й фантасмагоричними образами дивного ж «роману у віршах» Й. Гете, в якому не людське єднання, а здіймання духу до абстракції Віри формує видіння єдності як чистої ідеальності мислення про Спасіння. Як відомо, фаустіанство Ф. Ліста складало невід'ємну частку його способу життя, не менше, ніж його Віросповідання, яке привело його до прийняття сану абата. Вибір Веймара для композиторського буття творця «Фа- 
уст-симфонії» був підказаний також місцеперебуванням історичного Фауста (що зумовило вибір Веймара і для місця проживання Й. Гете).

Ф. Ліст усвідомлював свою буттєву сутність у паралелях з Фаустом, спорідненість з яким вбачав у збігу й протиспрямованості латинізованої шанувальної версії імені Фауста - Фаустус, що значить «яскравий, веселий», тоді як німецький зміст його прізвища «Ліст» (німецьке List - «веселість, хитрість, лукавість, підступність») утворювала морально протилежну, «проміфестофельську» якість. У історичного Фауста і у самого Ф. Ліста був друг-супутник Вагнер (від лат. wagus - блукач). Даний розклад «містики обставин» вказував, виходячи з усього, на антиномічність людської сутності творчого дару композитора-виконавця, що надихала явно автора «Фауст-симфонії» на ототожнення свого єства з історичним позауніверситетським професором XVI ст. Мефістофельська якість виявляла іншу іпостась в його динамічній натурі.

I якщо кантіанське ідеалотворення через мистецьку активність надихало Ф. Шиллера та Л. Бетховена на реалії людського братерства через діяльнісну спільність творчих зусиль, то у Ф. Ліста духовне братерство складало здобуток Споглядання Істини - Вічно-жіночого-Богородичного, усвідомлюваного в нерозривності з грішним падінням, спокутуваним готовністю жертвувати і дитям, і собою.

Порівняння дат написання творів за Дев'ятою симфонією Л. Бетховена вказує, що виділена на початку даної роботи «Фауст-симфонія» Ф. Ліста (1854-1857) займає дещо серединне положення не за часовими пропорціями співвіднесення дат написання названих композицій, але за змістом наслідування і жанрового рішення: єдиний у вигляді циклу представлений симфонічний твір з трьома оркестровими і фрінальною кантатною частинами. Пряма співвідносність конструкції композицій Л. Бетховена і Ф. Ліста поєднана з протиспрямованістю ідеї, від чого, можливо, у описах цього твору Ф. Ліста автори $[1 ; 6 ; 11 ; 13]$ не оговорюють очевидну спадкоємність. І вказана змістовна протиспрямованість $є$ відверто ідейно-релігійною, що складає певний антипафос щодо заклику Шиллера-Бетховена «обійматися мільонам» попри релігійні розмежування.

Таким чином, ідея-принцип «Фауст-симфонії» Ф. Ліста виходить за межі мистецько-художньої цілісності, оскільки остання органічно представлена у I-III частинах, проти виконання яких без фіналу автор не заперечував [6, 255]. Але все ж «Фауст-симфонія» була структурована композитором в повноті чотиричастинного циклу, в якому є свій Шлях до Височині, втіленої за текстом у символіці Вічножіночого жертовною готовністю перетворюючого грішні пристрасті і Спокутою, що рятує світ. Як бачимо, в ідеологічному вираженні тут маємо дещо несумісне з шиллерівським текстом і кантіанськими перевагами Л. Бетховена: релігійна жертовність затуляє тут світіння мистецької Краси, яка усвідомлюється у Ф. Шиллера й Л. Бетховена у значенні Божественої суті.

І якщо тема Радості у Л. Бетховена базується на жанрі канта, на музиці одухотворенної співдружності, то у Ф. Ліста Заключний хор, що оспівує Вічно-жіноче, показує відверто церковну псалмодію. Вона репрезентована чоловічими голосами, тобто саме у храмовому оспівуванні Ідеї жіночості, високої абстракції вираження жертовно-жіночого начала, а не у театральному наслідуванні звучанню жіночих голосів. Такого роду закінчення Симфонії підготовлене кодою III частини, теж побудованої на темі Маргарити з II частини Симфонії. Тільки в Andante soave Маргарита представлена більш приземлено, у вигляді «пісні-арії без слів», в якій моторний акомпанемент мелодії у високому регістрі (у гобоя), супроводжуваний фігураціями альта, демонструє впізнаваний від Ф. Шуберта ідеалізований побутовий образ «Маргарити за прядкою».

Аріозні втручання (мелізматичні фрігури) у пісенний образ суттєві, оскільки закладається той високий стиль вираження, який виявиться у коді скерцо «Мефістофель», а ще більшою мірою - у вище характеризованому Завершальному хорі. Як бачимо, представлені три фрази заявлення образу Маргарити, перша з яких (II частина Andante soave, «Гретхен») демонструє побутовий зріз образу, ідеалізований характер якого виявляється завдяки міфологізаційним паралелям: діва, що пряде аналог античним Паркам, Норнам з германської міфології.

Наступний етап подання образу Маргарити - кода III частини (Росо andante, ma sempre alla breve), тема Маргарити - у валторни і віолончелі, тобто це вже не безпосереднє подання жіночої фрігури, це її символізація: тема позбавлена рис «пісні без слів», проходить на фоні педалей струнних і духових. А завершальний етап, як вже відзначалося - суто символічний, церковно-абстрагований: це втілення Радості, але даної у Спогляданні, у якості Видіння ідеального початку світу, зведеного до Вічно-жіночого.

Вказаний ракурс Радості, заявленої у Л. Бетховена, постає найбільш безпосередньо втіленим із усієї сукупності проекцій «синдрому Дев'ятої симфонії» і одночасно найбільш відсторонено-звужено: жіночий внесок у буяння маскулінного світу.

Наукова новизна статті зумовлена самостійністю підходу до розуміння смислу проекцій генія Л. Бетховена у творчі звершення романтичної доби, оригінальністю герменевтичного аналізу риторичних вимірів виразності творів Ф. Ліста та інших авторів.

Висновки. Вперше у культурологічних і мистецтвознавчих дослідженнях виділене кантіанство Л. Бетховена як змістовна ідея Преображення світу мистецтвотворенням в його романтичній символізації, в якій очевидним є зменшення соціального обґрунтування ідеального початку і наростання риторичної умовності втілення, спрямованого до мрії-Марення символістів - на матеріалі бетховеніанства 
М. Глинки, Р. Вагнера, Г. Малера і спеціально виразності «Фауст-симфонії» Ф. Ліста. Остання подає Видіння жіночого початку світу як Радість-Втіху у вирії маскулінного дисгармонічного буття.

\section{תimepamypa}

1. Альшванг А. Людвиг ван Бетховен. Очерк жизни и творчества. М.: Советский композитор, 1971. 560 с.

2. Андросова Д. Мінімалізм в музиці: Учбовий посібник для вузів мистецтв. Одеса: Астропринт, 2008. 126

C.

3. Асафьев Б. Музыкальная форма как процесс. Книги 1 и 2. М.: Музыка, 1971. 379 с.

4. Асафьев Б. Симфонические этюды. Л.: Музыка, 1971. 264 с.

5. Барсова И. Симфонии Густава Малера. М.: Советский композитор, 1975. 496 с.

6. Друскин М. История зарубежной музыки. Вторая половина XIX века. М.: Музыка, 1980. Вып. 4. 528 с.

7. Кино. Энциклопедический словарь. М.: Советская энциклопедия, 1986. 640 с.

8. Конен В. История зарубежной музыки. М.: Музыка, 1972. Выпуск третий. Германия, Австрия, Италия, Франция, Польша с 1789 года до середины XIX века. 526 с.

9. Маркус С. История музыкальной эстетики в 2-х томах. М.: Музгиз, 1959. Т. 1. 316 с.

10. Мильштейн Я. Ф. Лист: в 2-х т. М.: Музыка, 1970. Т. 1. 864 с.

11. Музыка Французской революции XVIII века. Бетховен. М.: Музыка, 1967. 443 с.

12. Соната // Музыкальная энциклопедия в 6-ти томах. Т. 5 СИМОН-ХЕЙЛЕР. М.: Советская энциклопедия, 1981. Стлб. 193-200.

13. Łobaczewska S. Beethoven. Kraków, PWM, 1977. 239 s.

\section{References}

1. Alschwang, A. (1971). Ludvig van Beethoven. The Essay to lifes and creative activity. Moscow: Sov. Kompozitor. [in Russian]. Ukraine].

2. Androsova, D. (2008). Minimalism in music. Scool appliances for universities of arts. Odesa: Astroprint. [in

3. Asafiev, B. (1974). Music form as process. Books first and sekond. Moscow: Muzyka. [in Russian].

4. Asafiev B. (1971). Symphonic etudes. Leningrad: Muzyka. [in Russian].

5. Barsova, I. (1975). Gustav Mahler's Symphonies. Moscow: Sov. Compozytor. [in Russian].

6. Druskin, M. (1980). History of the foreign music. The Second half XIX age. Moscow: Muzyka. [in Russian].

7. Cinema (1986). Encyclopedic dictionary. Moscow: Sov. Encyclopedia. [in Russian].

8. Konen, V. (1972). The History of the foreign music. The Issue third. Germany, Austria, Italy, France, Poland since 1789 before medium XIX century. Moscow: Muzyka. [in Russian].

9. Markus, S. (1959). History of the music aesthetics in 2-h volumes. V.1. Moscow: Muzgiz. [in Russian]. Russian].

10. Milshtein Ja. (1970). F. Liszt. Publishing second, extended and complemented. V. 1. Moscow, Muzyka. [in

11. 11. The Music to French revolution XVIII century. Beethoven (1967). Moscow: Muzyka. [in Russian].

12. Sonata (1981). Misical encyclopedia in 6 volumes. Moscow: Sov. encyklopedija. pp. 193-200. [in Russian].

13. Łobaczewska, S. (1977) Beethoven. Kraków, PWM. [in Polish].

Стаття надійшла до редакції 23.05.2019 p. 